\title{
Green Smart Cities: Living Healthily with Every Breath
}

\author{
Cihan Turhan \\ Department of Mechanical Engineering \\ Izmir Institute of Technology \\ Izmir/Turkey \\ cihanturhan@iyte.edu.tr
}

\author{
Ali Serdar Atalay \\ BitNet Corporation \\ Izmir/Turkey \\ serdar@bitnet.com.tr
}

\author{
Gulden Gokcen Akkurt \\ Department of Energy Systems \\ Engineering \\ Izmir Institute of Technology \\ Izmir/Turkey \\ guldengokcen@iyte.edu.tr
}

\begin{abstract}
Fifty-four percent of the world's population lives in big cities and it is projected to increase to nearly $70 \%$ by 2050s. Rapid and dense urbanization leads to smart cities which improve the quality of lives of the citizens. Therefore, development of smart cities is becoming vital. The quality of the citizens is affected by many factors including poor air quality, increased pollutants and microclimates called urban heat islands. The URBAN GreenUP project, initiated in June 2017, is a project funded under the European Union's Horizon 2020 programme. The main objective of the project is the development, application and replication of re-naturing Urban Plans in a number of European cities. In this study, measurement of nature-based solutions for mitigation of urban heat island effect and improvement of air quality for Urban GreenUP project in Izmir, will be introduced.
\end{abstract}

Keywords - air quality, nature based-solutions, smart cities, urban heat islands

\section{INTRODUCTION}

A smart city is an urban area that incorporates information and communication technologies (ICT) to enhance the quality and performance of urban services such as energy, transportation and utilities in order to reduce resource consumption, waste and overall costs (Fig. 1). The overarching aim of a smart city is to enhance the quality of living for its citizens through smart technology [1]. To transform itself into a smart city, a city has many areas in which it can act. Six basic directions for action will enable it to direct its objectives along this route, according to the definition of "smart" (Fig. 2) including smart economy, smart governance, smart environment, smart mobility, smart population and smart living environment [3].

Smart cities put data and digital technology to work with the goal of improving the quality of life. More comprehensive, real-time data gives agencies the ability to watch events as they unfold, understand how demand patterns are changing, and respond with faster and lower cost solutions.

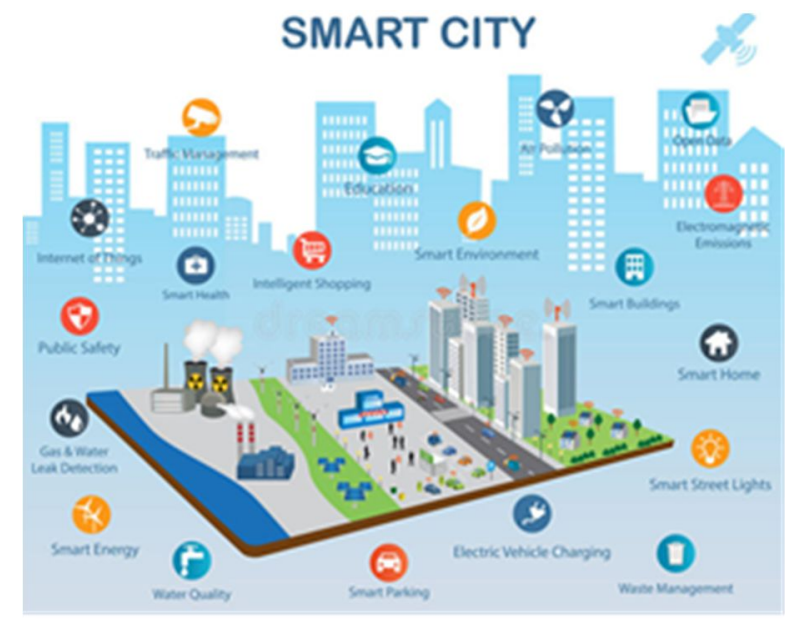

Fig. 1. Components of a smart city [2]

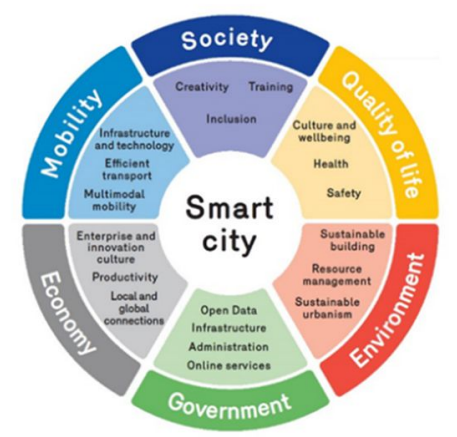

Fig. 2. Basic directions of a smart city [3]

Smart cities can deliver a cleaner and more sustainable environment. As urbanization, industrialization, and consumption grow, environmental pressures multiply. While technology is only one option for addressing these issues, it can be a powerful one. Based on a report published by McKinsey [4], deploying a range of smart city applications to the best reasonable extent could cut greenhouse gas emissions by $10-15 \%$.

Some of the energy-saving and mobility applications could improve air quality as a secondary benefit. To tackle this issue more directly, cities can install air quality sensors. They do not automatically address the causes of pollution, but they can identify the sources and provide the basis for further action. Beijing reduced deadly airborne pollutants by roughly $20 \%$ in less than a year by closely tracking the sources of 
pollution and regulating traffic and construction accordingly. Sharing real-time air quality information with the public via smartphone apps enables individuals to take protective measures, potentially reducing negative health effects by 3$15 \%$, depending on current pollution levels [4].

Several studies show that increasing the green areas in the urban environment has considerable positive health effects such as reduction in chronic stress and stress-related diseases [5]; cognitive and social development in children [6]; increase of number of people being physically active, which is directly related to have less likelihood to suffer a cardiovascular disease [7] and to reduce potentially autoimmune diseases and allergies [8].

Urban Heat Island (UHI) is an urban or metropolitan area that is significantly warmer than its surrounding rural areas due to human activities [9]. As a population center grows, it expands its area and increase average temperatures. One of the main causes of the UHI is the fact that there is little bare earth and vegetation in urban areas. This means that less energy is used up evaporating water, less of the Sun's energy is reflected and more heat is stored by buildings and the ground in urban than in rural areas. The heat generated by heating, cooling, transport and other energy uses also contributes, particularly in winter, as does the complex three dimensional structure of the urban landscape (Fig. 3). According to USEPA, some of the key effects of UHI includes increase of energy consumption, poorer air quality and more greenhouse gasses (aggregation impact), negative impact on human health and comfort and thermal pollution of water [10].

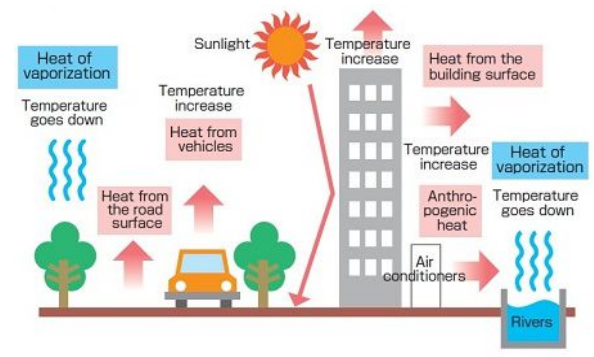

Fig. 3. Urban Heat Island and how it occurs [10]

The URBAN GreenUP project, initiated in June 2017, aims to contribute to the mitigation of climate change risks in cities, increase the resilience to climate change effects and improve air quality through developing and adopting naturebased solutions (NBSs) and creating sustainable green areas. The project will raise awareness about the benefits of renaturing cities exhibiting nature-based solutions by front runner cities-İzmir-Turkey, Valladolid-Spain and LiverpoolEngland.

In this paper, NBSs for mitigation of the impact of UHI effect and improvement of air quality in İzmir-Turkey for Urban GreenUP project, will be introduced. Three Sub Demo Sites (A, B and C) were selected for the implementation and the measurement techniques were also discussed.

\section{METHODOLOGY}

The method includes a general description of İzmirTurkey, selection of three Sub Demo Sites (A, B and C) and measurement techniques of the air quality and the impact of UHI measurement techniques that will be applied for the project.

\section{A. Case of Izmir}

Izmir, which is located in Csa type climate zone according to Köppen-Geiger classification [11], is the third most populous city in Turkey. The average monthly temperatures are in excess of $22^{\circ} \mathrm{C}$ in the warmest month (July) and an average in the coldest month (January) between 18 to $-3^{\circ} \mathrm{C}$ with at least four months above $10^{\circ} \mathrm{C}$ [12].

Izmir is considered as an important city in the view of heat wave risks and their results such as health problems and thermal discomfort. Table 1 depicts the intensive heat waves and the maximum air temperature of summer months between 1938 and 1998 for Izmir [13].

TABLE I. . INTENSIVE HEATWAVES IN IZMIR [13]

\begin{tabular}{|c|c|c|c|}
\hline \multicolumn{4}{|c|}{ Intensive Heatwaves } \\
\hline Months & June & July & August \\
\hline Times & 7 & 12 & 11 \\
\hline $\begin{array}{c}\text { The maximum air } \\
\text { temperature }\end{array}$ & $41.3^{\circ} \mathrm{C}$ & $42.6^{\circ} \mathrm{C}$ & $40.1^{\circ} \mathrm{C}$ \\
\hline
\end{tabular}

Road transport and construction operations are identified as major sources of air pollutants in cities. Airborne particulate matter is associated with harmful effects on human cardiovascular and respiratory health. Particles $\leq 10$ microns (PM10), and particularly the finer particles $\leq 2.5$ microns (PM2.5) associated with road transport vehicles, are of concern due to their small size; (a micron, or micrometre $=$ one-millionth of a meter: 0.001 millimetre). Green walls (or screens) in urban streets may act as barriers to direct dispersal of pollutants from combustion engine vehicles to pedestrian areas. Particulates may be deposited on the leaf surface of trees or taken up into the leaf surface wax layer, reducing atmospheric particulate concentrations. According to Yatkin and Bayram [14], the dominant contributor to PM was traffic with $>70 \%$ at urban and sub-urban sampling locations in Izmir. Izmir has highly urbanised areas with dense population and traffic and close to Industrial Zones. The total greenhouse gas $\left(\mathrm{CO}_{2}+\mathrm{CH}_{4}+\mathrm{NO}_{2}\right)$ emissions of the industry accounts for $44 \%$ while buildings are responsible for $12 \%$. Therefore, Izmir is under the effect of both industrial and building effluents. On the other hand, domestic heating is the most polluting sector contributing about $56 \%$ of total PM emissions while traffic has the highest share in $\mathrm{NO}_{\mathrm{X}}$ emissions. Especially, emissions from industries located outside the metropolitan area are much higher in amount. Industries located around the Izmir metropolitan area contribute to the industrial $\mathrm{SO}_{2}$ emissions by $93 \%$, PM emissions by $59 \%$ and $\mathrm{NO}_{\mathrm{X}}$ emissions by $80 \%$ of the total [15]. The volatile organic compound (VOC) concentrations around the petrochemical complex and oil refinery close to Izmir, were observed as 420 times higher than those measured at a suburban site in İzmir. The $\mathrm{CO}_{2}$ emission per capita in Izmir is 5.31 tonnes/year. However, pollutants level never exceeded the EU levels [16].

NBSs are implemented and monitored for three Sub Demo Sites (A, B and C) in Izmir. Sub-Demo A is deployed in the central area of Karşıyaka metropolitan area which is highlyurbanized and Sasalı Natural Life Park. NBSs of Sub Demo A includes arboreal areas, green parklets, smart soil into green shady structures, green pavements and covering shelters, and green shady structures. Sub Demo B is deployed in Sasalı 
Natural Life Park which is designed by Izmir Metropolitan Municipality and is recently considered to extend its activity through new ecologically sensitive developments. NBSs of the Sub Demo B includes non-technical interventions using urban farming and activities that enhance bio-diversity. Sub Demo C includes Peynircioğlu River and a $10 \mathrm{~km}$ long green corridor from the coastal areas and river beds to highly sensitive nature protection areas. Green pavements along Peynircioğlu River, green fences, fruit walls and cycle and pedestrian route in green corridor are the NBSs of Sub Demo C [17].

\section{B. Assessment of NBSs}

The European Commission introduced the EKLIPSE project to help building up an evidence and knowledge base on the benefits and challenges of applying NBSs. The aim of the EKLIPSE activity is to devise an impact evaluation framework that can guide the design, development, implementation and assessment of NBS demonstration projects in urban contexts. NBSs are monitored based on ten challenges indicated in the EKLIPSE report [18]. A set of Key Performance Indicators (KPIs) is selected based on the report [18] that show the proposed actions and monitoring systems for NBSs in URBAN GreenUP project (Table 2).

TABLE II. KPIs USED IN URBAN GREENUP PROJECT

\begin{tabular}{|c|c|c|}
\hline $\begin{array}{l}\text { CHAL } \\
\text { LANG } \\
\text { ES }\end{array}$ & $\begin{array}{l}\text { TYPE OF } \\
\text { INDICATOR }\end{array}$ & KPI DEFINITION \\
\hline \multirow{5}{*}{1} & \multirow{2}{*}{$\begin{array}{l}\text { Environmental } \\
\text {, Chemical }\end{array}$} & $\begin{array}{l}\text { Tonnes of carbon removed or stored per unit } \\
\text { area per unit time }\end{array}$ \\
\hline & & Total amount of carbon stored in vegetation \\
\hline & \multirow{2}{*}{$\begin{array}{l}\text { Environmental } \\
\text {, Physical }\end{array}$} & $\begin{array}{l}\text { Decrease in mean or peak daytime local } \\
\text { temperatures }\end{array}$ \\
\hline & & Heatwave risks \\
\hline & Others & $\begin{array}{l}\text { Use of Star tools to calculate projected } \\
\text { maximum surface temperature reduction }\end{array}$ \\
\hline \multirow{8}{*}{2} & \multirow{4}{*}{$\begin{array}{l}\text { Physical } \\
\text { indicators }\end{array}$} & $\begin{array}{l}\text { Run-off coefficient in relation to precipitation } \\
\text { quantities }\end{array}$ \\
\hline & & $\begin{array}{l}\text { Absorption capacity of green surfaces, } \\
\text { bioretention structures and single trees }\end{array}$ \\
\hline & & Temperature reduction in urban areas \\
\hline & & $\begin{array}{l}\text { Areas (Ha) and population (inhab) exposed to } \\
\text { flooding }\end{array}$ \\
\hline & \multirow{2}{*}{$\begin{array}{l}\text { Chemical } \\
\text { indicators } \\
\text { (water quality) }\end{array}$} & Drinking water provision \\
\hline & & Water for irrigations purposes \\
\hline & \multirow{2}{*}{$\begin{array}{l}\text { Economic } \\
\text { indicators } \\
\text { (benefits) }\end{array}$} & $\begin{array}{l}\text { Volume of water removed from water } \\
\text { treatment system }\end{array}$ \\
\hline & & $\begin{array}{l}\text { Volume of water slowed down entering sewer } \\
\text { system }\end{array}$ \\
\hline 3 & N.A & Not selected \\
\hline \multirow{5}{*}{4} & \multirow{2}{*}{$\begin{array}{l}\text { Social } \\
\text { indicators } \\
\text { (benefits) }\end{array}$} & $\begin{array}{l}\text { Accessibility (measured as distance or time) } \\
\text { of urban green spaces for population }\end{array}$ \\
\hline & & $\begin{array}{l}\text { Weighted recreation opportunities provided by } \\
\text { Urban Green Infrastructure }\end{array}$ \\
\hline & \multirow{3}{*}{$\begin{array}{l}\text { Environmental } \\
\text { (biological) }\end{array}$} & Production of food \\
\hline & & Increased connectivity to existing GI \\
\hline & & Pollinator species increase \\
\hline \multirow[b]{3}{*}{5} & \multirow[t]{2}{*}{$\begin{array}{l}\text { Environmental } \\
\text { (chemical) }\end{array}$} & $\begin{array}{l}\text { Annual mean levels of fine particulate matter } \\
\text { (e.g. PM2.5 and PM10) in cities concentration } \\
\text { recorded ug/m3 }\end{array}$ \\
\hline & & Trends in emissions NOX, SOX \\
\hline & Economic & $\begin{array}{l}\text { Monetary values: value of air pollution } \\
\text { reduction; total monetary value of urban } \\
\text { forests including air quality, run-off } \\
\text { mitigation, energy savings, and increase in } \\
\text { property values. use of GI Val to calculate the } \\
\text { value of air quality improvements }\end{array}$ \\
\hline
\end{tabular}

\begin{tabular}{|c|c|c|}
\hline & $\begin{array}{l}\text { Social } \\
\text { (physiological }\end{array}$ & Air quality parameters $\mathrm{NOx}, \mathrm{VOC}, \mathrm{PM}$ etc. \\
\hline \multirow[t]{2}{*}{6} & $\begin{array}{l}\text { Urban green } \\
\text { indicators } \\
\text { (environmental } \\
\text {, biological) }\end{array}$ & $\begin{array}{l}\text { Accessibility: distribution, configuration, and } \\
\text { diversity of green space and land use changes } \\
\text { (multi-scale ;). - Green spaces quantity }\end{array}$ \\
\hline & $\begin{array}{l}\text { Socio-cultural } \\
\text { indicators }\end{array}$ & Savings in energy use due to improved GI \\
\hline 7 & Social & $\begin{array}{l}\text { Perceptions of citizens on urban nature - } \\
\text { Green spaces quality }\end{array}$ \\
\hline 8 & $\begin{array}{l}\text { Social } \\
\text { Cohesion }\end{array}$ & Green intelligence awareness. \\
\hline \multirow[b]{2}{*}{9} & $\begin{array}{l}\text { Psychological } \\
\text { indicators }\end{array}$ & $\begin{array}{l}\text { Noise reduction rates applied to UGI within a } \\
\text { defined road buffer } \mathrm{dB}(\mathrm{A}) \mathrm{m}-2 \text { vegetation unit }\end{array}$ \\
\hline & $\begin{array}{l}\text { Health } \\
\text { indicators } \\
\text { related to } \\
\text { ecosystem } \\
\text { service } \\
\text { provision } \\
\end{array}$ & $\begin{array}{l}\text { Increase in walking and cycling in and around } \\
\text { areas of interventions }\end{array}$ \\
\hline 10 & Economic & Number of jobs created; gross value added \\
\hline
\end{tabular}

The KPIs are based on the EKLIPSE framework, where a robust set of KPIs shall be selected and established by challenges that relate to NBSs. These challenges are climate mitigation and adaptation, water management, coastal resilience, green space management, air quality, urban regeneration, participatory planning and governance, social justice and social cohesion, public health and well-being, potential of economic opportunities and green job.

NBSs can improve air quality, minimize heatwaves, act as carbon stores and help to mitigate climate change. Furthermore, they can also provide a multitude of benefits that impact on human health, lifestyle and well-being.

\section{Air quality measurements}

Measurement of the air quality parameters is complex; involving many potentially interacting variables. Variation in weather conditions; prevailing wind direction and speed; tree species, density, location and structure; and the configuration of built urban infrastructure are among factors which may affect the trajectory and rate of dispersal of particulate pollutants. This study aims to compare outdoor air concentrations of PM10 and PM2.5 at child and adult head heights at locations with and without street trees or green walls to evaluate whether these NBSs are associated with reduced local concentrations of airborne PM10 and PM2.5.

In the project, air concentrations of PM2.5 and PM10 will be measured at sampling points at a range of radii from NBS street and tree/green wall locations both pre- and postintervention. Measured data will be then compared to the measurements taken at equivalent locations on equivalent stretches of road without street trees/green wall at a similar time of day on the same dates.

\section{C.I. Portable Sensor}

A portable photometric sampler will be used to measure ambient PM2.5 and PM10 concentrations [19] (Fig. 4). A laser and optical sensor are fitted to the sensor head of the monitor to measure light scattered from particles passing through a laser beam. The scattered light is transformed to electrical signals to provide mass measurements of PM2.5 and PM10. Data stored on the device will be downloaded later to a PC using the USB cable and software provided with the monitor. 


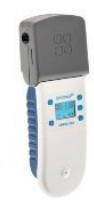

Fig. 4. Sensor used for air quality measurement [19]

At each study site and control site, depending on the width between road and street buildings, a sample will be taken at pre-determined locations: $\boldsymbol{a}$ ) at the roadside, $\boldsymbol{b}$ ) 3-5 $\mathrm{m}$ from the road (where street trees/green walls have been installed the NBSs should be situated between this sampling point and the road) c) $6-10 \mathrm{~m}$ from the road; with additional measurements at intervals at greater distances from the road for study sites where urban infrastructure constraints allow. Both intervention and matched control study sites will be sampled on the same occasion during each round of samples (i.e. an intervention site and matched control are sampled on the same date and at as close a time of day as possible). Each pre-determined sampling location at a study site will be repeat sampled every 4 weeks for a year pre-intervention (September 2018 to August 2019) and for two years following intervention (spring 2020 to spring 2022). At each sampling point two readings will be taken: at heights estimated to represent $\boldsymbol{a}$ ) child and $\boldsymbol{b}$ ) adult head heights.

Data will be downloaded to a PC from PM monitor using bundled software and exported to Excel (xlsx or csv file). The annual mean levels of PM10 and PM2.5 are calculated at each sampling location. Finally, the annual mean values for NBS intervention and control sample locations are compared at each study site.

\section{C.II. Low-cost air quality sensor pack}

The air quality sensors are expensive. In order to decrease the costs of sensors, a low cost air quality sensor pack is designed to measure PM10 and PM2.5 levels in project Demo Sites. Air quality sensor pack uses a particle sensor based on a laser-based sensor which uses the light scattering method to detect and count particles in the concentration range of 0 $\mu \mathrm{g} / \mathrm{m}^{3}$ to $1,000 \mu \mathrm{g} / \mathrm{m}^{3}$ in a given environment (Fig. 5).

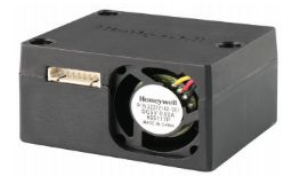

Fig. 5. Particle sensor used in air quality sensor pack

A laser light source illuminates a particle where the particle is pulled through the detection chamber. As particles pass through the laser beam, the light source becomes obscured and is recorded on the photo or light detector. The light is then analyzed and converted to an electrical signal providing particulate size and quantity to calculate concentrations in real time. The particle sensor provides information on the particle concentration for given particle concentration range. A microcontroller is used to receive the data from particle sensor and stores the measurements in a separate csv file (Fig. 6).

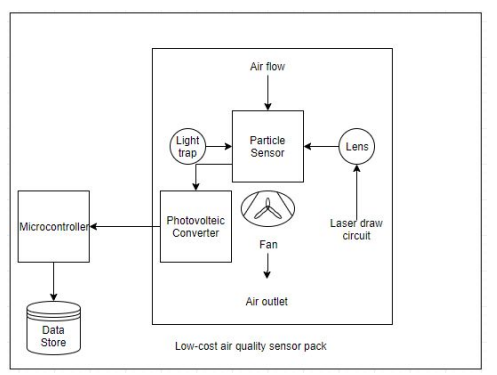

Fig. 6. Schema of low-cost air quality sensor pack

The low-cost air quality sensor pack has long life of 20,000 hours of continuous use essentially equates to seven years of product life based on eight hours of operation per day.

\section{D. . Urban Heat Island (UHI) impact measurements}

URBAN GreenUP project measures the UHI impact before and after the interventions of NBSs structures (such as green shady structures, green covering shelters, shade and cooling trees, cool, green pavements). In order to measure and compare impact of UHI, land surface temperature will be measured with Satellite and better granularity drone and in-stu thermal imaging. For an example, satellite image from 17 July 2017 over the city of Izmir was downloaded from the USGS website (Fig. 7). Afterwards, LST was retrieved using the LST tool in Erdas IMAGINE developed by [20].

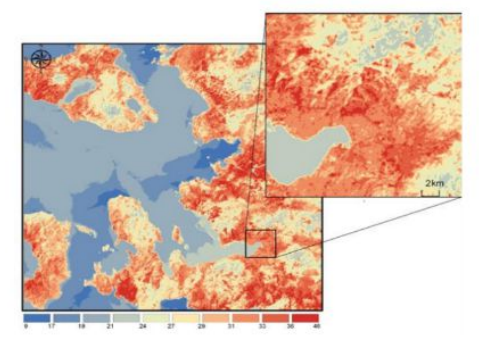

Fig. 7. 17 July 2017 LST - Izmir

Taking into consideration the dimensions of the Sub Demo A and Sub Demo B in this study, using Landsat-8 satellite imagery for observing the temperature differences before and after the building of the green roof over the parking spaces would not be very convenient. For such small areas, higher resolution remote sensing sensor is more appropriate. The ideal way to observe the changes from the green roof would be using high resolution Unnamed Areal Vehicle (UAV) with a thermal camera. With such UAV very high-resolution imagery can be obtained. However, since there have been several complications and both of the study areas are in restricted area, it was not possible to fly over the mentioned study areas. The observation of the temperatures is planned to be made in the summer period when the temperatures in the study area are significantly high. Using Optris IP-450 thermal camera, it is planned to measure the temperatures within the study area and its surroundings every hour in order to be able to get 24-hour temperature behavior of the different land covers. The measurements will be taken over the parking area, surrounding green area, trees, 
buildings, roads. Using zonal statistic, the temperature difference before and after the construction of the green roof will be calculated. Since area Sub Demo A and Sub Demo B have similar characteristics, the temperature difference will be easy to detect.

\section{CONCLUSIONS}

The URBAN GreenUP project aims to contribute to the mitigation of climate change risks in cities, decrease the impact of UHI and improve air quality through developing and adopting NBSs and creating sustainable green areas. The project raises awareness about the benefits of re-naturing cities exhibiting NBSs by front runner cities, İzmir-Turkey, Valladolid-Spain and Liverpool-England. In this paper, NBSs for mitigation of UHI effect and improving air quality in Izmir were introduced as well as measurement techniques were discussed in detail. Three Sub Demo Sites (A, B and C) and the NBSs according to the characteristics of each Site were explained.

The results of the NBSs on mitigation of UHI and improvement of air quality in Izmir will be published separately after extensive measurements.

\section{ACKNOWLEDGMENT}

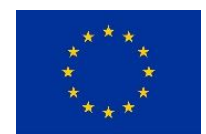

Urban GreenUP project has received funding from the European Union's Horizon 2020 research and innovation programme under grant agreement No 730426.

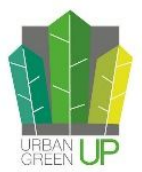

\section{REFERENCES}

[1] T. Nam and T.A.Perdo, "Smart city as urban innovation: focusing on management, policy, and context", Proceedings of the $5^{\text {th }}$ International Conference on Theory and Practice of Electronic Governance, pp. 185-194, September 26 - 29, 2011, Tallinn, Estonia .

[2] Dreamstime (2019, January 05) Available: https://www.dreamstime.com/stock-illustration-smart-city-concept-internetthings-different-icon-elements-modern-design-future-technology-livingimage 78407701

[3] Brussels Smart City (2019, January 06) Available : https://smartcity.brussels/the-project-definition\#

[4] McKinsey Global Institute, "Smart Cities: Digital solutions for a more livable future" June 2018.

[5] J.J. Roe, C. W. Thompson, P.A. Aspinall, M. J. Brewer, E.I. Duff, D.Miller,R. Mitchell and A. Clow, "Green Space and Stress: Evidence from Cortisol Measures in Deprived Urban Communities" Int J Environ Res Public Health. Vol.10(9), pp. 4086-4103, September 2013.

[6] E. Amoly, P. Dadvand, J. Forns, M. López-Vicente, X. Basagaña, J. Julvez, M. Alvarez-Pedrerol, M. J. Nieuwenhuijsen and J. Sunyer, "Green and blue spaces and behavioral development in Barcelona schoolchildren: the BREATHE Project", Environ Health Perspect, Vol. 122, pp.1351-1358, 2014.

[7] A. Tamosiunas, R. Grazuleviciene, D. Luksiene, A. Dedele, R. Reklaitiene, M. Baceviciene, J. Vencloviene, G. Bernotiene, R. Radisauskas, V. Malinauskiene, E. Milinaviciene, M. Bobak, A. Peasey and M.J. Nieuwenhuijsen, "Accessibility and use of urban green spaces, and cardiovascular health: Findings from a Kaunas cohort study", Environ. Heal. Vol. 13, pp. 20, 2014.

[8] M. Kuo, "How might contact with nature promote human health? Promising mechanisms and a possible central pathway", Front Psychol. vol. 6, pp. 1093, 2015.
[9] T. Hung, D. Uchihama, S. Ochi and Y. Yasuoka, "Assessment with satellite data of the urban heat island effects in Asian mega cities", Int. J. Appl. Earth Obs. Geoinf., vol. 8(1), pp. 34-48, 2006.

[10] United States Environmental Protection Agency, Available: https://www.epa.gov/heat-islands.

[11] Koppen Geiger, Retrieved from http://koeppen-geiger.vuwien.ac.at/shifts.htm, Retrieved Date: 05.01.2019.

[12] TurkStat, 2017. Reports of Turkish Statistical Institute.

[13] E. Erlat, İzmirde Maksimum Sicaklıklar ve Sicak Dalgaları, Ege Coğrafya Dergisi, vol. 10 , pp. 125-148, 1999 (In Turkish).

[14] S. Yatkin and A. Bayram, "Source apportionment of PM(10) and $\operatorname{PM}(2.5)$ using positive matrix factorization and chemical mass balance in Izmir, Turkey", Sci Total Environ., Vol. 390(1), pp. 109-23, 2008.

[15] T. Elbir, and A. Müezzinoğlu, "Estimation of emission strengths of primary air pollutants in the city of İzmir, Turkey" Atmospheric Environ. vol.38, pp. 1851-1857, 2004.

[16] Izmir Metropolitan Municipality Reports , 2017.

[17] URBAN GreenUP 4.1, Report on the Diagnosis of Izmir, www.urbangreenup.eu, 2017.

[18] EKLIPSE, An Impact Evaluation Framework to Support Planning and Evaluation of Nature-Based Solutions Projects, An EKLIPSE Expert Working Group Report, Centre for Ecology and Hydrology, Wallingford, United Kingdom, 2017.

[19] Aeroqual Air Quality Sensor, Available: https:/www.aeroqual.com/

[20] U. Avdan and G. Jovanovska, "Algorithm for automated mapping of land surface temperature using LANDSAT 8 satellite data", Journal of Sensors, vol.1, pp.1-8, 2016 